\title{
21. China, Nature, and the Sublime in Kant
}

\author{
Eric S. Nelson
}

\section{Introduction}

Naturalistic and anti-humanist accounts of early Lǎo-Zhuāng (老莊) Daoism and of the uncanny or terrifying sublime suggest that the everyday life and conventional personality of the individual is interrupted and displaced by overwhelming impersonal powers that reveal the "human" to be a false construction and the world an aesthetic, natural, or mystical play of forces. ${ }^{1}$ This is often portrayed as entailing an either/or between anthropocentric humanism, with all of its questionable assumptions about "the human" as distinct from animals and the natural world, and an impersonal naturalism that seems to depersonalize and de-individuate the person.

I will examine whether there is an alternative to both of these onesided perspectives and argue that human beings can be individuated within and in the context of their natural world. Such a natural and yet still ethical individuation can be glimpsed in the work attributed to the ancient Chinese thinker Zhuāngzì (莊子), the Zhuāngz $\iota^{2}$, and in Immanuel Kant's Critique of Judgment. According to standard readings,

1 I would like to thank Dan Lusthaus for his comments and challenging questions that have helped improve this essay. Note that I adopt the terms "Early" or "Lăo-Zhuāng" Daoism for the sake of convenience. This convention does not imply that there is an underlying unity or school between them nor does it necessarily include or exclude other varieties of Daoism.

2 The Zhuāngzí (莊子) passages are cited by chapter. I have consulted the Library of Chinese Classics Chinese-English edition of the Zhuangzi by Wang Rongpei, Qin Xuqing, and Sun Yongchang (Changsha: Hunan People's Publishing House and Foreign Language Press, 1999); Burton Watson's The Complete Works of Chuang Tzu (New York: Columbia University Press, 1968); Martin Palmer's The Book of Chuang Tzu (London: Penguin/Arkana, 1996); A.C. Graham's Chuang-Tzu: The Inner Chapters (Indianapolis: Hackett, 2001); Hyun Höchsmann and Yang Guorang, Zhuangzi (New York: Pearson Longman, 2007); and Brook Ziporyn, Zhuangzi: The Essential Writings (Indianapolis: Hackett, 2009). 
this is a hopeless strategy to the extent that Kant is concerned with the person's transcendence and Zhuāngzì with its natural immanence. Further, these radically divergent texts have no shared language, kinship, or identity.

Instead of advocating a hidden affinity, a critical reading of both reveals that Kant's third Critique goes beyond his more typical complicity with the anthropocentric domination of nature and that the Zhuanngzi does not eliminate individuality and the human in its skeptical challenging of conventional human perspectives and concern with dào (道) and tiāndi (天地, heaven and earth, or "nature”). Between Kant and Zhuāngž̀, there is an open or empty space for considering individuality in the context of the natural world.

This essay relies on a reinterpretation of the Zhuāngzl $l$ as an ethics of natural yet not inhuman individuation and responsiveness in order to examine Kant's problematic interpretation of China and its "mysticism", involving a troublesome racial-aesthetics, and Kant's articulation-more evocative of early Daoist approaches to nature and Chinese aesthetics - in the Critique of Judgment of nature as free natural beauty and the sublime. ${ }^{3}$ By stressing human responsiveness to free natural beauty, Kant proves there is more than the human domination of nature as either: (1) a constituted product or (2) mere objects of use and exploitation. Still, in the core of the third Critique, it appears as if the sublime reveals nature to be more than the human world only in the end for it to be lesser than human dignity. Kant's sublime risks endangering the person while disclosing the possibility of reaffirming the dignity of the individual in relation to the natural world. If that dignity is not affirmed, the person is overwhelmed in the adventurous or the grotesque. It remains to be seen if the awe and terror of the sublime is the possibility not of a dignity and vocation outside of the world but of renewed individuation in relation to the forces of nature.

3 I argue for the ethical orientation of early Daoism in E.S. Nelson, "Responding with dao: Daoist Ethics and the Environment", Philosophy East West 59:3 (July 2009), 294-316; and "Questioning Dao: Skepticism, Mysticism, and Ethics in the Zhuangzi", International Journal of the Asian Philosophical Association 1:1 (2008), 5-19. 


\section{Kant and China: Aesthetics, Nature, and Race}

Deploying an aesthetics of race, or racial aesthetics, Kant attributed qualities to the various races of the world in his Observations on the Feeling of the Beautiful and Sublime (1764). Kant identified Asian Indians and the Chinese with the moral-aesthetic category of the "grotesque", remarking of the latter (2:252):

What ridiculous grotesqueries do the verbose and studied complements of the Chinese not contain; even their paintings are grotesque and represent marvelous and unnatural shapes, the likes of which are nowhere to be found in the world. They also have venerable grotesqueries, for the reason that they are of ancient usage, and no people in the world has more of them than this one.

Earlier in the Observations, Kant described the category of the grotesque used in this passage, undoubtedly revealing a lack of understanding of Chinese practices and painting, as a gradation of the sublime $(2: 214)$ : "Unnatural things, in so far as the sublime is thereby intended, even if little or none of it is actually to be found, are grotesqueries." The initial examples thereof are: duels, cloisters, graves of saints; castigation, vows, monkish virtues; Ovid's Metamorphoses; and the empty subtleties of Scholastic philosophy $(2: 214-5)$. The grotesque is correlated by Kant with the "weaker understanding" of the fantast and crank $(2: 222)$ - that is, with what he considered to be enthusiastic dabbling in fantastic fiction and/or the mystical, such as Ovid (whom Kant continued to quote in his works) and Emmanuel Swedenborg, and with the ritualism, scholasticism, and superstition he associated with pre-modern Catholic Europe.

Kant does not appear to have ever changed his negative stance toward what he considered Chinese. Nor did he ever share Leibniz and Wolff's affirmative reception of various aspects of Chinese philosophy, politics, and ethics, where ideas and practices from China are seen as examples that can instruct modern Europeans. ${ }^{4}$ Kant's apparent hostility toward the non-European world is not limited to China. This has been explained by reference to increasing European colonial activity and the escalating disrespect for other ways of life as inferior and to be subjugated, although Kant was critical of colonization and slavery,

4 On the relation of Leibniz and Wolff to China, see E.S. Nelson, "Leibniz and China: Religion, Hermeneutics, and Enlightenment", Religion in the Age of Enlightenment, vol. 1 (CITY: PUBLISHER??, 2009), 277-300. 
as well as by Kant's problematic development of the discourse of race in a scientific or pseudo-scientific language. ${ }^{5}$

In his 1764 work Kant is extending to the other peoples of the world categoriesthat are simultaneously anthropological, moral, and aesthetic, and are first used to classify other Europeans, including the "phlegmatic" Germans. The stereotypes of the Chinese being overly refined and cunning, superstitious and ritualistic, are elucidated through the category of the grotesque. As marvelous and stultified, as somehow inhuman and unnatural, Kant is suggesting, without clarifying in detail, that it is a misrelation to the sublime. Whereas the sublime ought to evoke awe or terror, yet always returns the observer to the dignity and moral vocation of the human, gradations of the sublime such as the adventurous and the grotesque leave the self, and accordingly human dignity and moral personhood, lost in the powers of nature and tradition.

Kant repeatedly returned to the loss of the person in nature that he perceives in the East. Unlike Leibniz and Wolffs positive reception of China, and akin to Malebranche's condemnation of the Chinese for being Spinozistic, Kant's lectures on religion from the mid-1780 s associate Asian thought with the mystical experience of nature, assimilating it to Spinoza (28:1052):

To expect this [e.g., divine participation] in the present life is the business of mystics and theosophists. Thus arises the mystical self-annihilation of China, Tibet, and India, in which one deludes oneself that one is finally dissolved into the Godhead. Fundamentally one might just as well call Spinozism a great enthusiasm as a form of atheism.

Such an atheistic mysticism or enthusiastic naturalism is incoherent according to Kant, since it breaches the transcendental separation between immanence and transcendence, the sensible and its conditions and the supersensible whereof nothing cognitively meaningful can be stated. Kant's depiction in this passage targets not only Buddhism but also Daoism, given his interpretation of its identification with the monstrous and grotesque in "The End of All Things". In language that partly evokes

5 Compare Robert Bernasconi, "Will the Real Kant Please Stand Up: The Challenge of Enlightenment Racism to the Study of the History of Philosophy", Radical Philosophy 117 (2003), 13-22; "Who Invented the Concept of Race? Kant's Role in the Enlightenment Construction of Race", in R. Bernasconi (ed.), Race (Oxford: Blackwell, 2001), 11-36. 
the rú (儒) or Confucian disapproval of Buddhism and Daoism that probably informed his sources, Kant claimed (8:335):

From this [improper dabbling in the transcendent] comes the monstrous system of Lao-kiun [i.e., Lǎož (老子)] concerning the highest good, that it consists in nothing, i.e., in the consciousness of feeling oneself swallowed up in the abyss of the Godhead by flowing together with it, and hence by the annihilation of one's personality; in order to have a presentiment of this state Chinese philosophers, sitting in dark rooms with their eyes closed, exert themselves to think and sense their own nothingness. Hence the pantheism (of the Tibetans and other oriental peoples); and in consequence from its philosophical sublimation Spinozism is begotten ...

In line with Christian ontotheology, Kant interprets the nothing and nothingness as primarily negative and pantheism as its celebration rather than as the affirmation of things and life in their immanent significance. Friedrich Nietzsche turned these two elements, nothingness and the self-affirmation of life in its immanence, against each other in his critique of Buddhism and the Asiatic. Ironically, Kant's portrayal of the Chinese was applied to Kant in Nietzsche's abuse of him as "der große Chinese von Königsberg" and "das Königsberger Chinesenthum"; with such labels Nietzsche seems to have some combination of moralism, mysticism, and ritualism in mind. ${ }^{6}$ Nietzsche's polemical identification is obviously insufficient either to excuse Kant or link Kant and Chinese philosophy in any serious way. Even if Kant had more knowledge of Chinese thought, he might have further identified Daoism with the fantastic, akin to Ovid, Spinoza, or Swedenborg, and Confucian philosophy with the ritualism and scholasticism of Catholicism. Such associations are not unfamiliar in some recent and better informed authors who should know better. ${ }^{7}$

Instead of concluding with Kant's questionable judgments about the Chinese, or the affinities Nietzsche intimates, the following sections concern the relation between the human and the natural by reexamining the significance and import of (1) the beauty of "free nature" and of the sublime in Kant's philosophy and (2) what evokes free natural beauty and the sublime in the Zhuāngzi and, to a lesser extent, the Dàodéjing.

6 Friedrich Nietzsche, Sämtliche Werke: Kritische Studienausgabe in 15 Bänden (KSA), ed. Giorgio Colli and Mazzino Montinari (Berlin: de Gruyter, 1980): KSA, 5.144; KSA, 6.177; compare S.R. Palmquist's discussion in "How 'Chinese' was Kant?," The Philosopher 84:1 (Spring 1996), 3-9.

7 On the problematic assumptions of Western sinology, see the preface to Russell Kirkland, Taoism: The Enduring Tradition (London: Routledge, 2004), xi-xx. 
In the next section I inquire into whether the third Critique can be interpreted as a middle ground between impersonal nature and moral personality. In the last sections, I consider whether Lăo-Zhuāng Daoism truly dissolves the human into mystical nature, as both Kant and Confucian critics of early Daoism contend. Rather than being mystical absorption in the static unity of the one, it might well indicate the possibility of independent ease within changing nature, just as Kant wrote of English gardens and Baroque design (5:126)—although cultivating natural worldly freedom is not merely a project of the imagination in early Lăo-Zhuāng Daoism-by "[pushing] the freedom of the imagination almost to the point of the grotesque, and [making] this abstraction from all constraint by rules the very case in which taste can demonstrate its greatest perfection in projects of the imagination."

\section{A Daoist Reading of Nature in Kant's Third Critique}

Kant's anthropological speculations concerning the Chinese are part of the dubious development of Enlightenment discourses about race, yet his depictions of the grotesque and the sublime and of absorption into the inhuman persist as questions, given the continuing significance of Kant's thought and contemporary debates concerning the actuality, import, and value of the idea of the human person. Kant's impoverished assessment of Daoism remains to some extent recognizable in newer approaches that celebrate or fear the loss of the person. The works attributed to Lǎozì and Zhuāngzǐ continue to be associated with tendencies appearing to deny the moral personality of the individual. These tendencies include the mystical, the naturalistic, the anti-humanistic, and according to detractors whom I have responded to elsewhere, even inhumane and totalitarian government. ${ }^{8}$

The Zhuāngzl in particular is a work full of stories of fantastic transformations that undermine constant identity and threaten moral dignity and responsibility, celebrating the anarchistic and aesthetic playfulness of life and being free and at ease in the world, as well as philosophical dialogues and reflections that have become a focal point for discussions of skepticism and deconstruction that reveal conventional human action,

8 I describe and respond to a number of such criticisms by elucidating early Daoism's ethical dimension in "Questioning Dao", 5-19, and "Responding with dao," 294-316. 
knowledge, and values to be uncertain. In the context of post-humanist and postmodern interpretations of the uncanny and terrifying sublime, and of mystical and deep ecological approaches to nature, challenging the metaphysical assumptions that privilege the human in anthropocentric humanism and personalism, both skeptical and mystical depictions of early Daoism are interpreted as implying that the everyday personal life of the individual is interrupted, dismantled, and undermined or transformed by overwhelming and/or more elemental impersonal powers. ${ }^{9}$ The person and the human are accordingly revealed to be artificial constructions, with the world being an aesthetic, natural, or mystical play of inhuman forces.

Despite the third Critique and the Opus Postumum, Kant's philosophy of nature was criticized in German Romanticism for neglecting the vitality and holism of nature and, in works such as Adorno and Horkheimer's Dialectic of Enlightenment, for deepening the instrumental domination and exploitation of nature. ${ }^{10}$ For such authors, the Critique of the Power Judgment is too little, too late, or simply inconsistent, in addressing nature as a vital interdependent whole or in an environmentally sensitive way. ${ }^{11}$ Insofar as nature receives value in the end only in relation to human feeling, thought, and dignity, and thus has no independence in relation to the human, it is clear which side Kant falls on in the conflict between an anthropocentric humanism that values the person at the expense of the natural world and animal life, and an impersonal naturalism (whether scientific, romantic, or mystical) where the person disappears as transient part or composite.

9 Note that Jean-Francois Lyotard rejected the overly simplistic identification of the sublime with a politics of the sublime that would be terror and its celebration in The Postmodern Explained: Correspondence, 1982-1985 (Minneapolis: University of Minnesota Press, 1993), 67-71.

10 Theodor Adorno and Max Horkheimer, Dialectic of Enlightenment, tr. Edmund Jephcott (Stanford: Stanford University Press, 2002), and continues in Adorno's later works such as Beethoven: The Philosophy of Music, tr. E. Jephcott (Stanford: Stanford University Press, 1998), 80; History and Freedom, tr. R. Livingstone (Stanford: Stanford University Press, 2007), 209-10.

11 As, for instance, in Ann A. Pang-White, "Nature, Interthing Intersubjectivity, and the Environment: A Comparative Analysis of Kant and Daoism," Dao: A Journal of Comparative Philosophy 8 (2009), 61-78. As implied by the argument of this essay, I slightly disagree with the conclusion that nature in the third Critique is inconsistent or that Kantian transcendental subjectivity and worldly phenomenalism are more compatible with early Daoism and environmental ethics. 
The sensual-material or naturalistic moment is to some degree recognized in Kant's Critical philosophy: first, in the first Critique's principle of phenomenality that, however, leads back to the transcendental power and unity of consciousness; second, in the empirical and causal motivations that the person ought to overcome through the moral law; and, third, in the sublime that risks destroying the person while disclosing the possibility of reaffirming the dignity of the individual in relation to the natural world. By placing it at risk, the abyss and terror of the sublime heightens the feeling of life (Lebensgefühl) and, through its temporary interruption, the mind's own striving is shown to break with its absorption in sense-objects and surpass "every measure of the senses" (5:250).

Kant's account of the feeling of life is historically connected with early modern discourses of vis viva in Leibniz and the more materialist notion of the conatus in Hobbes and Spinoza. These concepts concern individuation in relation to the forces of nature, which for Kant is a question of moral sensibility and vocation. In relation to the forces and conditions of life, humans find their own purpose in themselves and individuate themselves as moral beings in a worldly context. Whereas the beautiful "carries with it directly a feeling of life's being furthered" (5:245), the sublime "is a pleasure that arises only indirectly; it is produced by the feeling of a momentary inhibition of the vital forces followed immediately by an outpouring of them that is all the stronger." Such moral individuation in response to nature is not the subsumption of a particular under a universal category or the exemplarity of a type, as with determinate judgment, and thus not the pure dominion of active spirit over passive nature.

Instead of being the assimilative drive and mastery of the self-interested conatus, as some critics have interpreted Lebensgefühl, it is the unpredetermined responsive and reflective generation, formation, and cultivation of individual and social aesthetic and moral sensibilities in relation to particular phenomena. The feeling of life is the possibility of a prereflective awareness of self and other. Without a predetermined concept, it involves the nexus of nature as significant in itself and human feeling that cultivates nature's significance, even if sensibility must transcend the senses and sensuality to realize its rational vocation for Kant. The third Critique is not only a work about the generation and articulation of concepts. It concerns the coming to word and concept of what is heterogeneous, not given, or without a concept $(20: 202-3)$ : 
the sensuous, the natural, and the felt in art and genius, language, and the sensus communis.

The sensus communis is a sharing of sense proceeding through feelings rather than a common understanding working through concepts $(5: 238,293)$. It is without a determinate concept or judgment and is universally communicable in requesting assent as distinct from legislating agreement $(5: 216,221)$. As such, it allows for the interpretation and communication of the non-cognitive and non-conceptual, particularly feeling. ${ }^{12}$ It constitutes a field of preunderstandings that do not only have the conservative function of reproducing custom, habit, and tradition, since it is communicative and can be open to and transformed by the new. The height of individuation in Kant is the genius who discovers ideas and ways of expressing them $(5: 317)$. Although restricted by the demands of rationality unfolded in the three Critiques, genius provides new forms and models for encountering and interpreting phenomena and oneself, as the genuinely and transformational "otherwise" has an important role in approaching society, culture, and art.

In the Critique of Judgment, Kant explored how nature can be judged reflectively as having purposes, humans can be said to be ultimate purposes, and art can embody and enact "purposefulness without purpose" as "lawfulness without law" or purposiveness without a concept of a determinate teleological final cause. This playful and anarchic removal of barriers and predetermined purposes in experiencing the free-form of the beautiful - for example, what is free in not being grounded in the concept of how the object ought to be or in an idea of purpose or perfection $(5: 222,229)$ - and the formlessness of the sublime is connected with the feeling of life and contrasted with the seriousness of ethical, political, and religious purposes as governed by fixed forms and final ends.

The "unison in the play of the powers of the mind" is not a confused concept or inadequate idea but a feeling of inner sense $(5: 228)$. Such felt spontaneity and playfulness, as the promise of freedom from a predetermined purpose and as responsiveness in relation to the forces and conditions of life, indicates a non-instrumental, non-coercive, and non-dominating activity understood as a creative receptiveness or responsive spontaneity in encountering the myriad things and the world as an ineffable whole inviting further investigation and inquiry. ${ }^{13}$

12 Rudolf Makkreel, Imagination and Interpretation in Kant (Chicago: University of Chicago Press, 1990), 164.

13 On the spontaneity and responsiveness of life, note Makkreel, 106, 156. 
Kant's third Critique does not, therefore, purely defend either the aesthetic use or moralistic domination of nature, as critics such as Günter Wohlfart contend. It is deeply ethical in locating the individuation and self-articulation of the person in a worldly, sensuous, and bodily as well as a social context. ${ }^{14}$ The self does not cognitively or theoretically know itself. Instead the self finds itself, according to the third Critique, in its comportment, cultivation (Bildung), and culture in relation to nature, the sublime, and the supersensible. ${ }^{15}$ As argued by John Zammito and others, this work was partly Kant's reply to the pantheism controversy that impacted German intellectual life in the late $1780 \mathrm{s.}{ }^{16}$ As opposed to being primarily reactive against pantheism and early romanticism, both clearly rejected by Kant, the third Critique articulates an alternative or middle ground affirming the person in relation to the forces and conditions of nature through feelings of life such as those of the beautiful and the sublime. Whatever their relation to the human faculties, Kant insists that both the beautiful and sublime please intrinsically, for themselves, rather than instrumentally, for something else, and that their purposiveness cannot be reduced to purposes - that is, instrumentally to human purposes.

Kant's approach to the feeling of life, reflective judgment, and sensus communis in the Critique of Judgment are ways of non-mechanistically, yet not metaphysically or teleologically in the strong sense, experiencing and articulating the nexus of life. They are non-mechanistic insofar as Kant describes the beautiful as free of calculative and instrumental interest, and the sublime as contrapurposive, addressing nature through a reflectively articulated purposiveness without a predetermined purpose. This nexus of life involves both the "external" natural world and the "internal" relations of the faculties of the subject.

14 In writings such as Die Kunst des Lebens und andere Künste: Skurrile Skizzen zu einem eurodaoistischen Ethos ohne Moral (Berlin: Parerga Verlag, 2005), Günter Wohlfart contends that Kant's philosophy is tied to an individualistic domination of nature and Daoism liberates us from such problematic individualistic humanism. For a condensed version of Wohlfart's argument, see his essay in the present collection (ch.23). If my argument is correct, Kant's thought is more open to nature and Daoism to ethics and the individual than Wohlfart contends.

15 Kant, 5:265; on the sublime and supersensible conditions of the subject and its moral cultivation, compare Makkreel, 79-81, 83-4.

16 John Zammito, The Genesis of Kant's Critique of Judgment (Chicago: University of Chicago Press, 1992), 6-12, 228-48. 
The analysis offered here places Kant's Critical philosophy in a different light, as having a "hermeneutical" dimension insofar as the human subject intrinsically lacks the transparency of self-knowledge (at least as a rationalistically intelligible essence) yet does live from the feeling of life that opens up questions of the self-understanding, interpretation, and individuation of that life. The proto- or quasi-hermeneutical aspects of the third Critique do not suspend or escape the conditions and demands of theoretical and practical reason. The book indicates strategies for a hermeneutics of "a" life or "individuated" life that do not rely on metaphysical self-knowledge or the rational psychology of the soul.

Kant's thought does not leave us with the bare mechanistic nature of the natural sciences nor return to a metaphysical or strong teleological conception of nature. It addresses questions of the formation and individuation of personal identity through reflective judgment and the sensus communis; these do not command or legislate to the phenomena but unresponsively or responsively interpret and communicate with them, in the context of the heightening and lessening of the "feeling of life" that seeks a balance and harmony in relation to itself and its world. ${ }^{17}$ Such dynamic harmony does not deaden the mind with a static unity, since it is animated and enlivened with the connections and resonance between what is different and singular (cf. 5:219).

The singular "this" indicated and addressed in feelings and judgments of taste- "this rose is beautiful", to use Kant's example-is distinct from the general or universal spoken of in logical judgments, including those that are aesthetically oriented, such as "roses are beautiful" $(5: 215)$. Whereas one evokes the experience of dynamic harmony with a particular, without subsuming it under a pre-given concept insofar as the concept is in need of being articulated, the other subsumes or synthesizes particulars according to a predetermined concept. As Makkreel notes of Kant's distinction, such harmony is a balancing instead of a determinate synthesis or totalization: "A harmony involves a reciprocal relation between two distinct elements; a synthesis, as Kant conceives it, involves a one-sided influence for the sake of a strict unity." 18

Kant's thinking of harmony in a play of forces and conditions, including in the face of the terror of the sublime (with the human disposition rising above sense objects and beginning to realize its non-sensu-

17 Makkreel, 3-6.

18 Makkreel, 47. 
ous and moral vocation), offers an alternative to: (1) an overly anthropocentric reading of Kant; and (2) Kant's own inadequate appreciation of Chinese painting, aesthetics, and early Daoism. In their own sensibility and language, the latter are about the harmony and balance within the individual (as the free, unforced balancing in play of flood-like $q i$ (氣), in contrast to Kant's language of the faculties) and in the individual's relations with the environing natural world that it transcends, without abandoning, in responding to things with freedom and ease. ${ }^{19}$

\section{Nature and Freedom in Kant and Early Daoism}

Kant associated the Chinese, Tibetans, and Indians with Spinozism. This indicates a lack of knowledge of both Spinoza and South and East Asian peoples and cultures - if not worse, since Bernasconi and others have concluded that Kant was systematically enthnocentric and racist. ${ }^{20}$ Despite Kant's actual racism, however, his thought surpasses these problematic motives. Thus, for example, his moral thought is radically egaliatarian in its scope, and-as shown in this essay-his thinking of the natural and the human is not as foreign to non-western ways of thinking as he himself thought or as critics such as Günter Wohlfart continue to argue.

In the Critique of Judgment, Kant explored both art and nature as embodying "purposefulness without purpose" or the form of purposiveness without a cognitively represented end or teleological final cause. This playful and an-archic lack of purpose is contrasted with the seriousness of ethical, political, and religious purpose, including the racial aesthetics and anthropology found in other works. Such spontaneity and playfulness, as freedom from a preordained purpose, can be analyzed in relation

19 Chapter four of the Zhuāngzi describes how it is by knowing without knowledge and by emptying the self through the "fasting of the mind" that one opens oneself to the spontaneous responsiveness of one's vital energy or force $(q i)$, receiving in sincerity and generously responding without assertion or imposition. See Höchsmann / Guorang, 103-4, Palmer and Breuilly, 29-30; Watson, 57-8; Ziporyn, 26-7.

20 In particular, R. Bernasconi, "Will the Real Kant Please Stand Up", 13-22, and "Who Invented the Concept of Race", 11-36. 
to the image and model of "free and easy wandering" unfolded in the Zhuāngzi. ${ }^{21}$

Such an analysis does not reveal any determinate parallels and analogies. It does, however, allow for the reconsideration of whether Kant privileged the human and neglected the natural and whether early Daoism neglected the human in prioritizing nature. These radically divergent perspectives offer two different articulations of a non-instrumental, non-coercive, and non-dominating activity understood as either (1) wandering free and at ease in the world or (2) a creative receptiveness or responsive spontaneity in encountering the myriad things and the world.

Whereas Kant emphasized the non-conceptual yet universal satisfaction enacted in the non-attached and free play of forces in aesthetic judgment, the Zhuāngzl articulates a non-conceptual and non-attached play that involves transitions between a multiplicity of perspectives. This includes the contra- or counter-purposive that Kant finds displeasing in the beautiful, despite the role he gives it in the sublime and his noting the beauty of the useless and hence free object $(5: 210-11,245)$. Instead of limiting this multiplicity and variability of transitions and perspectives to the freedom of the imagination and play in the aesthetic domain, and ultimately subordinating it to morality as in Kant's third Critique, the Daoist sage is portrayed as responsively free and at ease amidst the myriad things. ${ }^{22}$ Zhuāngz'̌s responding without retaining, acting upon without harming, is more expansive than any conditional and limited goal or purpose that would limit the self to its perspective without recognizing its inherent transience and multiplicity. Such responsiveness does notto speak Kant's language - presuppose and is not restrained by a determinate concept, even though it employs concepts and words that are unfixed yet not therefore meaningless. Liberation from the determinate, purposive, and useful enables human beings to relate to things and their context in a fundamentally different, non-instrumental way. This way

21 Due to space limitations, I have been able to develop the Daoist part of my argument only schematically. I refer those who are interested in Daoism to my articles: "Questioning Dao", 5-19, and "Responding with dao," 294-316.

22 Hyun Höchsmann and Christian Wenzel have addressed such concerns by stressing the practical-ethical character of freedom in both Zhuangzi and Kant in their respective articles: "The Starry Heavens above-Freedom in Zhuangzi and Kant", Journal of Chinese Philosophy 31:2 (June 2004), 235-52; and "Ethics and Zhuangzi: Awareness, Freedom, and Autonomy", Journal of Chinese Philosophy 30:1 (March 2003), 115-26. 
cultivates the self but is not therefore egotistical, since it calls on the self to individuate itself amidst things. It is naturalistic yet not thereby inhuman, if it is human to be oriented by and respond to heaven and earth.

Each of these works in its own way concerns individuation through cultivating balance in relation to nature within and outside oneself. Kant's third Critique and the Zhuangzzl are not simply aesthetic. They are deeply ethical works in (1) challenging the instrumental reduction of nature and the naturalistic reduction of the person or individual and (2) indicating the freedom in interaction and harmony between the human and the natural world. Nevertheless, Kantian and Daoist visions of freedom and balance in relation to self and world remain incommensurable.

Even as Kant recognizes nature's beauty and sublimity independently of calculative interests and limited purposes, he demands separation from nature for the sake of morality and the postulates of morality (freedom, immortality, and God), thereby rehabilitating theistic and transcendent religion, as argued in the third Critique's concluding pages. In contrast, although not without recognition of the transcendence or transformation within immanence, the Zhuangzian Daoist finds ethical independence dwelling within nature itself and disinterestedly embracing the myriad things in the immanence of their singular self-so-ness (zirán): following each being's own grain, including one's own, and accordingly discovering one's freedom in the midst of the world. ${ }^{23}$

23 This difference evokes Kant's critique of the self-sufficiency of morality (that it is its own reward regardless of hope in a future life) and nature (that it exists indifferently in and out of itself without regard for human hopes) in Spinoza, with which Kant associated Daoism $(5: 452)$. 